\title{
PEMIKIRAN HAMKA TENTANG PENDIDIKAN DAN RELEVANSINYA TERHADAP KONDISI SAAT INI
}

\author{
Ace \\ Universitas Ibn Khaldun Bogor \\ Jl. KH. Sholeh Iskandar KM. 2 Bogor \\ acedunsu@gmail.com
}

\begin{abstract}
Abstrak: Penelitian ini mengambil judul "Pemikiran HAMKA tentang Pendidikan dan Relevansinya terhadap Kondisi Saat ini". Tema tentang HAMKA ini memang sudah sering sekali diangkat dalam beberapa karya tulis, baik berupa buku, skripsi maupun tesis, namun penulis mencoba untuk melihat dari sisi yang berbeda yaitu dengan mengkaitkan pemikiran HAMKA terhadap kondisi saat ini.

Metode kualitatif digunakan dalam penelitian ini, yaitu kajian kepustakaan (library research) dengan cara mengumpulkan buku-buku karangan HAMKA sebagai data primer dan buku-buku lainnya yang menulis tentang HAMKA serta karya tulis berupa jurnal, skripsi maupun tesis untuk kemudian dikaji dan dianalisa sampai mendapatkan kesimpulan.

Dalam penelitian ini penulis membatasi penelitian hanya membahas dan mengkaji pemikiran-pemikiran HAMKA terhadap Pendidikan, khususnya pendidikan Islam di Indonesia. Dari hasil kajian ini penulis mencoba menstrukturkan proses munculnya pemikiran pemikiran HAMKA, sehingga tampak benang merah keterkaitan pemikiran Pendidikan HAMKA dengan Perjalanan Hidupnya.

Selanjutnya, penulis melakukan kajian analisis terhadap pemikiran HAMKA yang dihubungkan dengan kondisi saat ini, sehingga penulis menemukenali adanya relevansi pemikiran Pendidikan Islam HAMKA dengan kondisi keterkinian dan pada akhirnya bila ini diterapkan akan mampu membawa bangsa ini kepada kehidupan yang jauh lebih baik.
\end{abstract}

Kata Kunci: HAMKA, Pendidikan, Pendidikan Islam.

\section{PENDAHULUAN}

\section{A. Latar Belakang}

Kondisi saat ini Umat Islam dihadapkan kepada tantangan yang cukup berat dan kompleks yang menyangkut beberapa aspek

diantaranya:

Teknologi, khususnya Media

Telekomunikasi dan Informasi yang berkembang sedemikian pesatnya. Teknologi Internet mengawali perubahan yang sangat signifikan dalam kontruksi keterhubungan antar umat manusia dengan memanfaatkan infrastruktur telekomunikasi di seluruh dunia, sehingga membuat hubungan tidak lagi dibatasi oleh ruang, jarak, dan waktu, kapanpun dimanapun selama 
terhubung dengan akses Internet maka keterhubungan akan terjalin.

Kemudian ditambahkan dengan perkembangan Sosial Media yang semakin marak, mulai dari Facebook, Youtube, Twitter, Instagram dan lainlain semakin membuka gerbang dunia melalui dunia maya, informasi yang kirimpun tidak hanya terbatas pada suara, text (data) dan gambarpun setiap saat bisa di sebarkan luaskan.

Dengan fenomena tersebut, maka media penyebaran informasi semakin beragam dan sudah sangat personal dan menimbulkan salah satu dampak seperti semakin mudahnya berbagai informasi disampaikan. Beberapa yang termasuk diantaranya Ideologi, Pemikiran, Faham yang tidak hanya positif namun sarat juga dengan muatan-muatan negatif yang tidak bahkan sangat berbahaya bagi generasi saat ini pada umumnya, dan bagi generasi Umat Islam pada khususnya. Kondisi demikian akan semakin bertambah burk apabila generasi muda tidak dibentengi dengan pemahaman yang benar tentang Islam sebagai pondasi dasar dalam mengarungi kehidupan ini.

Munculnya gerakan - gerakan paham Neo-Liberalisme dan Sekulerisme yang sengaja dirancang dengan melakukan berbagai cara pendangkalan dan pembelokkan Aqidah dan Iman terhadap umat Islam. Gerakan ini dilakukan oleh sekelompok Orang atau Organisasi anti Islam yang tidak tampak dan ini akan sangat berpengaruh terhadap pemikiranpemikiran Islam yang murni dan benar atas dasar Al-Qur'an dan Hadist.

Menurut Hasbi Indra (2012: 6) dalam Bukunya "Pendidikan Islam Tantangan \& Peluang di Era Globalisasi” juga membahas tentang besarnya pengaruh arus globalisasi dalam kehidupan berbangsa dan bernegara termasuk umat Islam di Indonesia, seperti dalam salah satu pernyataanya yaitu "Menghadapi berbagai fenomena hidup yang ditandai oleh kemajuan dalam berbagai hal yang juga memunculkan dampak negatif, umat Islam dituntut berperan aktif dengan membenahi pandangan hidupnya yang juga memandang penting kehidupan kini, pentingnya kerja bersama umat dan ditengah pluralitas yang ada harus dihadapi dengan kelapangan dada dan jiwa yang shabar, serta berperan secara aktif atas hal yang bersifat riel kehidupan dengan berbagai problem kemanusiaan yang nyata yang harus segera diatasi." 
Melihat kondisi diatas, maka penulis mencoba menggali kembali pemikiran-pemikiran Pendidikan Islam dari generasi terdahulu yang sudah terbukti akhlak dan kredibilitasnya dalam ke-Islam-an nya dan dalam hal ini Pemikiran HAMKA yang Penulis angkat sebagai bahan Tesis untuk bisa meramu kembali Konsep Pendidikan Islam dalam rangka menjawab tantangan masa kini dan masa depan yang lebih baik.

Meskipun sudah banyak para akademisi yang membahas tentang pemikiran HAMKA, tetapi penulis memilih pemikiran-pemikiran beliau karena adanya keyakinan penulis bahwa Pemikiran Pendidikan Islam HAMKA masih sangat relevan untuk menjawab persoalan-persoalan Bangsa yang dihadapi saat ini. Terutama bagaimana Bangsa ini mempersiapkan generasi mudanya, khususnya generasi muda Islam untuk menghadapi pengaruh perkembangan teknologi dan gerakan-gerakan golongan anti islam yang terus berupaya melunpuhkan sendi-sendi kekuatan Islam di Indonesia, bahkan dunia.

\section{B. Perumusan Masalah}

Berdasarkan latar belakang yang telah dipaparkan diatas dan dengan melihat kondisi saat ini, agar penelitian lebih terarah, maka penulis merumuskan masalah penelitian sebagai berikut:

1) Bagaimana pemikiran HAMKA tentang pendidikan, khususnya pendidikan Islam?

2) Apakah Pemikiran Pendidikan HAMKA masih relevan dan mampu merespon Tantangan Umat Islam saat ini yang pada dasarnya dihadapkan kepada tantangan deislamisasi yang semakin marak melalui pendangkalan dan pembelokan akidah dan Iman oleh kelompok Anti Islam?

\section{Pembatasan Masalah}

Bila merujuk kepada karya-karya HAMKA, banyak sekali mutiaramutiara keilmuan yang telah beliau sumbangkan dalam khasanah keilmuan maupun kebangsaan, sehingga Jasa beliau sangatlah besar dalam sejarah Keilmuan dan Kebangsaan bagi bangsa Indonesia, lebih khususnya bagi Umat Islam. 
Sehubungan hal tersebut tidak mungkin pada tesis ini penulis mengupas seluruh pemikiran-pemikiran HAMKA di bidang keilmuan, ke Islaman, maupun kebangsaan. Oleh sebab itu, maka dalam penulisan Tesis ini penulis membatasi hanya membahas dan mengkaji tentang pemikiranpemikiran HAMKA terhadap Pendidikan, khususnya pendidikan Islam di Indonesia.

\section{Tujuan Penelitian}

Merujuk kepada perumusan masalah pada point (B) diatas, maka tujuan dari penelitian ini adalah pembuktian adanya Relevansi dari Pemikiran Pendidikan Islam HAMKA dengan kondisi saat ini, dimana umat islam dihadapkan pada tantangan deislamisai melalui Neo Liberalisme dan sekulerisme serta demoralisasi yang ditandai dengan semakin rendahnya moralitas manusia indonesia dalam hubungan sosial, berbangsa dan bernegara.

\section{E. Metode Penelitian}

1) Jenis Penelitian

Penelitian ini merupakan jenis kualitatif, berupa kajian kepustakaan (library research), yaitu penelitian yang mengumpulkan data dan informasi dengan bantuan bermacam-macam materi yang terdapat dalam kepustakaan (Arikunto 1995: 332).

Penelitian ini juga disebut Penelitian Kualitatif dengan menggunakan teknik penulisan deskriptif analitik. Metode deskriptif adalah metode yang digunakan untuk menggambarkan keadaan objek penelitian berdasarkan fakta yang tampak sebenarnya.

Analitik merupakan suatu proses mengulangi kekomplekan suatu gejala atau masalah rumit sampai pada pembahasan bagian-bagian paling elementer atau bagian-bagian paling sederhana. Hal ini menjelaskan bahwa tidak adanya pengujian suatu hipotesis tertentu, hanya akan menggambarkan apa adanya suatu variabel, gejala, keadaan (Arikunto 1995: 310).

\section{2) Sumber Data}

Dikarenakan penelitian ini merupakan studi kepustakaan, maka sumber data yang diperoleh berupa sumber kepustakaan. Sumber-sumber tersebut antara lain:
a. Sumber Primer
Untuk mendapatkan pemikiran- pemikiran
HAMKA tentang 
Pendidikan Islam, penulis melakukan pengamatan dan penlitian dari Karyakarya tulis yang langung dikarang oleh HAMKA, yaitu:

(1) Pribadi Hebat

(2) Lembaga Budi

(3) Falsafah Hidup

(4) Pandangan Hidup Muslim

(5) Keadialan Sosial dalam Islam

(6) Dari Lembah Cita-cita

(7) Buya Hamka Berbicara tentang Perempuan

(8) Tasawuf Modern

b. Sumber Sekunder

Terkait kemungkinan minim dan belum sempurnanya data dari sumber primer, maka dibutuhkan sumbersumber lain berupa sumber sekunder, yang antara lain buku-buku dan penelitian atau kajian sejenis yang berkaitan dengan masalah yang akan dibahas, diantaranya sebagai berikut :

(1) Samsul Nizar, Memperbincangkan Dinamika, Intelektual \& Pemikiran HAMKA tentang Pendidikan Islam, Jakarta: Kencana, 2008.

(2) Irfan Hamka, Ayah...Kisah Buya Hamka, Jakarta: Republika, 2013.

(3) Akmal Sjafril, Buya Hamka, Antara Kelurusan 'Aqidah dan
Pluralisme', Jakarta: Indie Publishing, 2012.

\section{3) Teknik Penggalian Data}

Data yang diperlukan dalam studi kepustakaan ini digali dari sumbernya melalui metoda KUALITATIF dengan riset kepustakaan (library research), yaitu mempelajari dan menelaah secara mendalam kandungan dari sumber primer tersebut. Di samping itu peneliti juga mempelajari dan menelaah bukubuku dan tulisan-tulisan serta karya ilmiah sebagai data sekunder yang terkait dengan pokok masalah yang diteliti. Kemudian data yang telah terhimpun dibahas dan selanjutnya dianalisa.

\section{PEMIKIRAN PENDIDIKAN HAMKA DAN RELEVANSINYA TERHADAP KONDISI SAAT INI}

Seperti dimaklumi bersama, bahwa tantangan generasi Islam di abad XXI ini tidaklah mudah apalagi di era Teknologi Informasi dan Komunikasi yang semakin maju dan bahkan dalam setiap aktivitas kehidupan hampir tidak terlepas dari TEKNOLOGI, terutama gadget, maka tidak heran kalau dalam dunia telekomunikasi dikenal dengan 
jargon "DUNIA DALAM beberapa sumber yang bisa GENGGAMAN". dipertanggung jawabkan.

Implikasi dari fenomena ini tidak ringan kemajuan Teknologi dan Informasi ini tentunya akan semakin mempercepat proses penyebaran berbagai Informasi, baik positif maupun negatif, termasuk diantaranya adalah Ideologi, Faham dan PemikiranPemikiran yang juga semakin beragam. Liberalisasi, Plurarisme, Sekulerisme, Relativisme, dan semacamnya adalah gerakan yang dilakukan oleh Kelompok Anti Islam dengan melakukan proses De ISLAMISASI melalui pendangkalan Iman dan Aqidah. Yang menjadi pertanyaan penulis adalah "Mampukah Generasi kita membendung derasnya Arus Informasi tersebut yang tentunya sangat mungkin meluluh lantakkan sendi-sendi ke Islaman dengan lemahnya Aqidah dan Iman Generasi Islam sekarang dan dimasa yang akan datang?".

Kuncinya adalah pendidikan, bagaimana pemerintah dan umat Islam pada khususnya mengelola dan mengembangkan Pendidikan di Indonesia dan dibawah ini Penulis mencoba mengulas secara lebih mendalam tentang Pemikiran Pendidikan HAMKA yang diambil dari

\section{A. GAGASAN HAMKA TENTANG PENDIDIKAN AGAMA ISLAM}

Seperti telah dibahas sebelumnya, bahwa pemikiran-pemikiran HAMKA sangat dipengaruhi oleh perkembangan pembentukan intelektualitasnya termasuk dalam pemikiran-pemikiran tentang Pendidikan Islamnyapun sangat diwarnai dengan hal tersebut. HAMKA sangat memahami bahwa pendidikan adalah unsur yang sangat penting dalam membentuk peradaban manusia yang dalam kontek Islam berujung kepada ketaatan, kepasrahan dan semakin mempertebal keimanan seseoarang kepada Allah SWT.

\section{1) Konsep Dasar dan Tujuan Pendidikan Islam}

Konsep dasar Pendidikan Islam menurut pemikiran HAMKA adalah didasarkan pada tiga aspek potensi peserta didik yaitu; jiwa (الفطرة) (القلب), Jasad (الجسم), dan akal (العقل) dengan tiga aspek tersebut jelas bahwa HAMKA lebih menekankan pemikiran pendidikannya pada aspek pendidikan jiwa atau akhlakul karimah (budi pekerti) yang dibentengi dengan 
AQIDAH yang kuat, seperti ulasan Azyumardi Azra dalam mengenai "Hamka dan urgensi Pendidikan Akhlak" (Nizar 2008).

Menurut Penulis Konsep dasar ini sangat dipengaruhi oleh pengalaman HAMKA diwaktu kecil pada Fase Inkubasi Intelektualitas. Pada fase ini HAMKA mendapat gemblengan langsung dari Ayahanda tercinta dengan diberikannya dasar-dasar Ilmu Agama berupa AQIDAH dan AHKLAK yang sedemikian menyatu dengan diri dan jiwa HAMKA, sehingga dalam perjalanan hidupnya membuat HAMKA menjadi pribadi yang kuat dan mampu membentengi dirinya dari pengaruh-pengaruh negatif, khususnya dalam pendangkalan Aqidah dan keimanan.

Bukti diri inilah yang sangat penting dari HAMKA, sehingga dengan kekuatan Intelektualitasnya HAMKA

Alshlak \& Aqidah

\section{Jiwa}

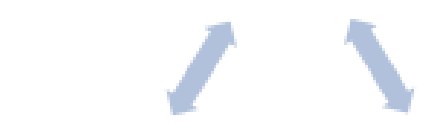

\section{Jasad}

\section{Akal}

\section{Curiosity Knowledge}

mampu mendefinisikan Konsep Dasar Pendidikan Islam. Disini penulis mencoba memberikan visualisasi dari konsep dasar tersebut seperti ditampilkan pada Gambar 1.

Dari gambar tersebut, ketiganya saling mempengaruhi dan yang paling penting adalah Jiwa mampu mengendalikan jasad dan akal, jangan sebaliknya, karena bila Jiwa nya kuat dan mampu mengendalikan akal dan jasad, maka Insan tersebut menjadi Insal Kamil atau Insan yang Paripurna. Jadi sangat beralasan, mengapa HAMKA sangat menekankan proses pembentukan awal dalam pendidikan adalah pemguatan AQIDAH dan AKHLAK.

\section{2) Kerangka Dasar Pendidikan Islam \\ Dari Buku "Memperbincangkan} Dinamika Intelektual dan Pemikiran HAMKA tentang Pendidikan Islam”

Gambar 1. Konsep dan Tujuan Pendidikan Islan

\section{Tujuan Pendidikan : \\ Mencarikeridhaan Allah (Aqidah) \\ - Membangun BudiPekerti untuk berakhlakMulia - Mempersiapkan kehidupan layak dan berguna}


yang dikarang oleh Prof. Dr.H. Samsul Nizar, M.Ag, pembahasan pemikiran HAMKA tentang kerangka dasar pendidikan Islam sudah sangat terstruktur, sehingga penulis mencoba untuk mensarikan dari paparan dalam buku ini.

Kerangka Dasar Pendidikan Islam menurut Pemikiran HAMKA meliputi aspek: Pendidik dan Peserta Didik, Materi Pendidikan, Kurikulum Pendidikan, Metode Pendidikan dan Model Lembaga Pendidikan.

\section{a. Pendidik dan Peserta Didik}

Mengamati Biografi perjalanan perkembangan Intelektualitas HAMKA, maka terlihat betapa strategisnya posisi seorang Pendidik dimata HAMKA, karena Pendidik akan sangat menentukan hasil akhir dari suatu proses pendidikan yang dijalaninya. HAMKA dalam perjalananya dipertemukan dengan tokoh-tokoh pendidik yang sangat Luar biasa dan tidak diragukan lagi Kualitas Pendidik nya, bahkan lingkungan yang membentuknyapun semakin memperkuat pembangunan Karakter dan Intelektualitas Seorang HAMKA.

Dalam Pandangan HAMKA, tugas seorang pendidik adalah membantu mempersiapkan dan mengantarkan peserta didik untuk memiliki ilmu pengetahuan yang luas. Sementara secara khusus, tugas pendidik meliputi : mengetahui tingkat perkembangan dan kemampuan peserta didik, membangkitkan minat belajar, membangkitkan dan mengarahkan potensi peserta didik, mengatur situasi proses belajar mengajar yang kondusif, mengakomondir tuntunan sosial dan zaman kedalam proses pendidikan serta melakukan interaksi dengan peserta didik, orang tua dan sosial secara harmonis (Nizar 2008: 136).

Gambaran kualitas seorang pendidik bagi HAMKA adalah orangorang yang selama ini telah berinteraksi dengan dirinya, dimana seorang pendidik disamping memiliki tingkat keilmuan yang luas dan dalam juga memiliki akhlak yang mulia ditambah dengan tanggung jawab profesi sebagai seorang pendidik yang memiliki rasa cinta (passion) dan tanggung jawab moral tinggi terhadap hasil didikannya (Nizar 2008: 138).

\section{b. Materi Pendidikan}

Pengembangan akal (filsafat) dan rasa (agama) adalah dua jenis orientasi materi pendidikan dan 
Menurut HAMKA, kedua orientasi materi tersebut penting dan saling mengisi antara satu dengan yang lain. Dalam konteks pendidikan Islam, maka penyampaian materi bahan ajar seyogyanya selalu mengkaitkan semua bidang keilmuan ke aspek spiritual keagamaan.

Jangan terjadi pemisahaan diantara keduanya, karena pemisahan keilmuan dari aspek sipitual akan menghasilkan generasi Materialistik yang bahkan mungkin tidak bermoral atau sebaliknya menghasilkan generasi yang menafikan dinamika peradaban dunia kekinian (Nizar 2008: 163).

Pembagian Materi Pendidikan menurut pemikiran HAMKA dibagi atas 5 bagian, yaitu: Ilmu-ilmu Agama (Tauhid, Fiqih, Tafsir, Hadist, Akhlak, dll), Ilmu-Ilmu Umum (Sejarah, Filsafat, Ilmu Bumi, Ilmu Falak, Biologi, Ilmu Jiwa), Ilmu Kemasyarakatan (sosiologi, ilmu pemerintahan, dll), Ketrampilan Praktis (berenang, berkuda, Olah Raga, dan lain-lain) dan Ilmu Kesenian (musik, menggambar, menyanyi, melukis, dan lain-lain) (Nizar 2008: 163-166).

\section{c. Kurikulum Pendidikan}

Kurikulum disusun, disiapkan dan dikembangkan untuk kepentingan pendidikan, terutama untuk mempersiapkan peserta didik agar mereka mampu hidup dan berinteraksi positif di tengah-tengah masyarakat. Peserta didik tidak hanya dituntut untuk mampu mengimplementasikan skill dan knowledge yang diperolehnya dari dunia pendidikan, namun harus mampu pula menerapkan tata nilai serta norma yang baik di dalam kehidupan bermasyarakat pada umumnya.

Dalam pendidikan Islam Kurikulum yang ditawarkan tidak cukup hanya sesuai dengan penjelasan diatas, namun dituntut untuk mampu menumbuhkan rasa sosial dan taqarub kepada Allah, sebagai bentuk pengabdian kepadanya. Dalam beberapa karyanya, HAMKA tidak secara eksplisit menjelaskan dengan rinci dan konkret bentuk kurikulum pedidikan yang ditawarkan, namun secara implisit paling tidak mencakup dua aspek, yaitu Pertama Ilmu-ilmu agama dan kedua adalh Ilmu-ilmu rasional, intelektual dan filosofis (Nizar 2008: 168). 


\section{d. Metode Pendidikan}

Diskusi, adalah bertukar pikiran antara dua orang atau lebih dengan cara berdialog dan menyampaikan berbagai pandangan yang argumentatif. Metode ini sangat disukai oleh HAMKA, karena beliau bisa mengepresikan pendapatnya sesuai dengan pemikiran dan pemahamanya. Proses yang demokratis, tidak memaksakan kehendak dan mempu saling menghargai pendapat orang lain adalah tata nilai yang menonjol dalam metode diskusi ini.

Darma Wisata, adalah metoda yang memasukkan unsur "experience" dengan membawa peserta didik kepada objek-objek yang terkait dengan materi pendidikan, tujuannya agar tumbuh kepekaan dan kepedulian terhadap lingkungan. Metode ini sering kali di lakukan di semua tingkatan pendidikan dan sangat bermanfaat bagi perserta didik, karena mereka bisamembandingkan langsung antara teori yang didapat dikelas dengan kenyataan yang terjadi diluar kelas.

Eksperimen, adalah metoda untuk membuktikan kebenaran dari teori yang diajarkan dengan melakukan serangkaian Observasi dan latihanlatihan untuk memperkaya dan memperdalam keilmuan materi pembelajaran. Metoda ini biasa disebut dengan praktikum yaitu mengajak peserta didik untuk mempraktekkan langsung teori-teori yang di ajarkan dan kemudian dilihat hasilnya, apakah sesuai atau tidak dengan teori tersebut. Metode ini sangat penting dalam proses belajar mengajar, karena dengan dipraktekan maka peserta didik akan mengalami langsung sehingga akan memperkuat pemahaman dan pendalaman dari materi yang diajarkan.

Resitasi atau Assignment, adalah metode yang dilakukan dengan memberikan tugas-tugas yang terkait dengan proses belajar mengajar, misalnya tugas PR, soal-soal, pembuatan makalah kelompok atau perorangan dan lain-lain.

Tujuan dari metode ini adalah untuk mengetahui sejauh mana pemahaman peserta didik terhadap materi pelajaran yang telah diberikan sekaligus untuk memupuk tanggung jawab bagi peserta didik. Dari penugasan-penugasan inilah, pendidik bisa melihat tingkat keberhasilan proses belajar dan mengajar di lembaga pendidikannya dan tentunya melakukan improvement untuk perbaikan kedepan. 
e. Model Lembaga Pendidikan

Tercatat dalam biografi HAMKA, bahwa HAMKA sangat berperan aktif dalam menghidupkan kegiatan aktivitas keagamaan di Masjid Agung Al-Azhar Jakarta. Masjid yang didirikan oleh Yayasan Pesantren Islam (YPI) tersebut bertujuan untuk membangun pesantren sebagai wadah pendidikan bagi pemuda-pemuda Muslim.

Bukan hanya sebagai mubaligh, namun juga untuk menjadi Kader Pembangunan Bangsa yang berakhlak dan berjiwa bersih (Hamka 2013: 245). Belajar dari pengalaman tersbut, maka menurut pandangan HAMKA, lembaga pendidikan yang ideal adalah model pendidikan yang dikembangkan pada pondok pesantren. Hal tersebut terjadi karena Pesantren mampu mengintegrasikan secara maksimal unsur-unsur yang menunjang dalam proses pendidikan Islam (didalamnya terdapat Ruang Kelas, Masjid, dan Asrama) (Nizar 2008: 187). ${ }^{1}$

${ }^{1}$ Esensi dari Model kelembagaan Pendidikan Islam dalam pendidikan Islam adalah kembalinya semua aktivitas kegiatan Umat Islam ke MASJID, sehingga Masjid

\section{B. RELEVANSI PEMIKIRAN PENDIDIKAN ISLAM HAMKA DENGAN KONDISI SAAT INI}

\section{1) Konsep Dasar dan Tujuan Pendidikan Islam}

Pada pemikiran Konsep dasar dan tujuan Pendidikan Islam, HAMKA memberikan penekanan yang sangat kuat pada pembentukan pondasi Agama (Aqidah) dan Akhlak bagi peserta didik. Dan ini mengandung makna, bahwa pondasi keagamaan seseorang (khususnya Aqidah) dan Akhlak merupakan komponen yang tidak boleh ditawar-tawar lagi, merupakan keharusan bagi peserta didik untuk difahami, dikuasai dan sudah menjadi kesatuan yang utuh dalam jiwa dan raganya peserta didik.

HAMKA dalam hal ini sangat yakin, apabila kedua komponen diatas sudah teraktualisasikan dalam diri peserta didik, maka gocangan, tantangan, hambatan atau godaan sebesar apapun tidak akan mampu menggoyahkan aqidah dan keimananan peserta didik dan pada akhirnya akan dihasilkan perta didik yang berkualitas serta mampu mencapai tujuan

menjadi bagian dari aktivitas terbesar umat Islam, termasuk didalamnya adalah Pendidikan Pesantren. 
pendidikan islam yaitu menjadikan manusi yang Insan Kamil (paripurna). Bila merujuk pada uraian diatas, dimana konsep pendidikan menurut HAMKA adalah didasarkan pada tiga aspek potensi (الفطرة) peserta didik yaitu; jiwa ( القلب ), Jasad ( الجسم), dan akal ( العقل ) dengan tiga aspek tersebut jelas dimana HAMKA lebih menekankan pemikiran pendidikannya pada aspek pendidikan jiwa atau akhlakul karimah (budi pekerti) yang dibentengi dengan AQIDAH yang kuat, maka penulis sepakat bahwa Pemikiran HAMKA ini MASIH RELEVAN, bahkan tidak hanya untuk saat ini tapi juga untuk masa yang akan datang.

Dengan kekuatan jiwa yang dibentengi oleh Aqidah dan Akhlak yang kuat, maka Jasad yang cenderung bergerak kearah duniawi (hubud dunya) dan akal yang cenderung mengarah kepada "logika" unsih dan mudah diombang -ambing kan dengan berbagai kemungkinan kebenaran menjadi tunduk kepada Jiwa, artinya JIWA sebagai pengendali Utama, sementara Jasad dan Akal adalah pihak yang dikendalikan. Dengan demikian maka, pemikiran HAMKA disini mampu meresponse kondisi yang terjadi saat ini dan sangat tepat untuk terus diterapkankan dan dikembangkan.

\section{2) Kerangka Dasar Pendidikan} Islam

Kerangka Dasar Pendidikan Islam menurut Pemikiran HAMKA meliputi aspek: Pendidik dan Peserta Didik, Materi Pendidikan, Kurikulum Pendidikan dan Model Lembaga Pendidikan.

\section{a. Pendidik dan Peserta Didik}

Pada bahasan dipoin (a) ini, HAMKA memberikan penekanan yang lebih kepada Pendidik. Pendidik menempati posisi yang sangat strategis dalam proses Pendidikan Islam, karena akan sangat menentukan tingkat keberhasilan pencapai tujuan pendidikan bagi peserta Didik.

Dikupas lebih dalam lagi bagai mana syaratnya menjadi seorang pendidik yang bila dipersingkat seorang pendidik adalah seseorang yang memiliki Aqidah yang kuat, akhlak yang mulia, Ikhlas, Sabar, sangat mencintai profesianya sebagai Pendidik dan memiliki keluasan dan kedalaman Ilmu pengetahuan.

Dalam kasus keterkinian, seringkali kita menemukan banyaknya Pendidik yang bila ditinjau dari segi kualitas ada di level rata-rata (tidak 
istimewa), sementara kebanyakan untuk generasi- genreasi muda yang memiliki kecerdasan lebih tinggi (diatas rata-rata), mereka cenderung lebih memilih profesi di luar Pendidik.

Bisa dibayangkan, bagaimana kualitas tenaga pendidik di era kemajuan teknologi yang sedemikian pesat, kualitas tenaga pendidiknya ratarata atau bahakan rendah. Belum lagi bis ditinjau dari sisi "PASSION" atau RASA CINTA terhadap Dunia Pendidikan, karena proses Rekrutmen nya bermasalah, mungkin lebih banyak yang terpaksa memilih propfesi ini, maka bisa dipastikan ketentuanketentuan yang dipersyaratkan sesuai dengan pemikiran HAMKA tidak akan terpenuhi, maka bisa dipastikan juga output dari hasil proses pendidikan nyapun berkualitas rendah.

Dari uraian diatas, maka penulis dapat menyimpulkan, bahwa pemikiran HAMKA tentang pendidikan islam yang menekankan kepada penting dan strategisnya posisi pendidik masih sangat relevan dengan kondisi saat ini, bahkan perlu diperahankan dan terus dikembangkan.

Dan Penulis yakin, bila proses rekrutmen Pendidik ini memenuhi standar kualitas pemikiran HAMKA, maka hasil didik nya akan luar biasa dan sesuai dengan tujuan Pendidikan Islam yang diharapkan.

Pembagian Lembaga Pendidikan dalam roadmap perjalanan pendidikan menuju Insan Kamil, sesuai pendangan HAMKA yang meliputi:

(1) Lembaga Informal, dimana proses pendidikan dimuali dari pendidikan Rumah Tangga atau Keluarga dan pada tahap ini tanggung jawab Orang Tua sangat besar dan dituntut agar mampu memberikan dasar-dasar yang kuat dalam pemahaman Agama (Aqidah) dan Akhlak dan kondisi dan situasi keluarga dijadikan sebagai miniatur pola berinteraksi sosial bagi sianak.

(2) Lembaga Formal, adalah tahapan lanjutan setelah peserta didik mendapatkan pendidikan dasar di Rumah Tangga. Peran Lembaga Formal ini, selain dalam rangka pengembangan kemampuan Keilmuan baik Umum maupun ke agamaan, juga sebagai miniatur pola interaksi antar peserta didik. HAMKA dalam hal ini lebih menekankan juga pada kualitas Pendidik yang disyaratkan kurang lebih sama dengan sebelumnya, 
yaitu seorang pendidik adalah seseorang yang memiliki Aqidah yang kuat, akhlak yang mulia, Ikhlas , Sabar, sangat mencintai profesinya sebagai Pendidik dan memiliki keluasan dan kedalaman Ilmu pengetahuan.

(3) Lembaga Non Formal, dalam pandagangan HAMKA lembaga ini lebih diarahkan kepada inisiatif dari si peserta didik dalam proses interaksinya dengan dunia diluar dirinya. Artinya interaksi sosial akan menjadi Lembaga Non Formal yang akan mewarnani kekuatan Intelektualitas peserta didik.

Pada dasarnya, pembagian lembaga pendidikan menurut pandangan HAMKA ini masih relevan dengan kondisi saat ini, mengingat proses Pendidikan anak bukan hanya menjadi tanggunga jawab lembaga pendidikan fromal, tetapi sesungguhnya menjadi tanggung jawab bersama dan dimulai dari rumah, sekolah maupun lingkungan. Bila ke tiga lembaga ini memiliki visi dan misi yang sama, maka penulis yakin output peserta didik yang dihasilkan akan sesuai dengan tujuan pendidikan Islam.

\section{b. Materi Pendidikan}

Dalam pandangan HAMKA, akal (filsafat) dan rasa (agama) keduanya menduduki posisi yang penting dalam pendidikan Islam. Dalam implementasinya harus seimbang agar tidak terjadi kecenderungan yang pada akhirnya akan menghasilkan generasi yang materialistik tak bermoral atau generasi yang tertutup dan menafikan kemajuan dan keterkinian.

Bahasan diatas, memberikan gambaran bahwa HAMKA adalah pribadi yang dinamis dan tidak kaku, sehingga tetap membuka ruang bagi adanya pembaruan-pembaruan dalam pendidikan tentunya dengan syarat tidak mempengaruhi Aqidah dan Akhlak, dalam konteks untuk kemajuan dan kemaslahatan bagi berbangsa dan bernegara kenapa tidak.

Dalam hal ini penulis berpendapat pemikiran HAMKA terkait dengan Materi Pendidikan masih reelevan. Apakah mampu meresponse kondisi keterkinian ? jawabnya ya namun dengan pengembangan dan penyesuaian keterkinian. 


\section{c. Kurikulum Pendidikan}

Kurikulum ini meskipun tidak secara explisit dibahas HAMKA dari berbagai karya tulisnya, namun secara implisit paling tidak mencakup dua aspek, yaitu Pertama Ilmu-ilmu agama dan kedua adalah ilmu-ilmu rasional, intelektual dan filosofis. Dari penjelasan diatas, maka penulis berpendapat pandangan diatas masih relevan dengan kondisi keterkinian.

\section{d. Metode Pendidikan}

Metode pendidikan yang digagas HAMKA yang terdiri dari Diskusi, Darma Wisata, Eksperimen Resitasi atau Assignment masih sangat relevan dengan kondisi saat ini.

\section{e. Model Lembaga Pendidikan}

Model lembaga pendidikan yang ideal menurut HAMKA adalah pesantren, karena mampu mengintegrasikan unsur-unsur yang mendukung proses pendidikan Islam berjalan. (Masjid, Ruang Kelas dan Asrama). Dan semua aktivitas atau kegiatan dikembalikan ke Masjid, termasuk didalamnya aktivitas pendidikan Islam.

Dari uraian diatas, maka penulis berpendapat pandangan HAMKA ini masih relevan dengan pengembangan. Apakah mampu merespon kondisi keterkinian, ya mampu merespon dengan pengembangan.

\section{KESIMPULAN}

Dari pembahasan karya tulis ini, maka penulis dapat menarik beberapa kesimpulan sebagai berikut:

1) Menurut Pemikiran HAMKA tujuan pendidikan Islam adalah untuk mencari keridhaan Allah, membangun Aqidah ke Islaman yang kuat dan budi pekerti yang tinggi, sehingga menghasilkan peserta didik yang berakhlak Mulia serta mempersiapkan peserta didik untuk hidup secara layak dan berguna ditengahtengah komunitas sosialnya.

2) Menurut pemikiran HAMKA, kerangka dasar dalam Pendidikan Islam meliputi aspek: a. Pendidik dan Peserta Didik; b. Materi Pendidikan; c. Kurikulum Pendidikan; d. Metode Pendidikan; dan e. Model Lembaga Pendidikan.

3) Dari seluruh Pemikiran HAMKA, terkait dengan Tujuan Pendidikan Islam maupun ke lima aspek Kerangka Dasar dalam 
Vol. 7 No. 2 Juli 2018

Pendidikan Islam, maka
pemikiran HAMKA tersebut
masih sangat relevan dengan
kondisi saat ini, baik dalam
menjawab tantangan serta
kebutuhan pendidikan Islam saat
ini bahkan untuk masa yang akan
datang.

\section{DAFTAR PUSTAKA}

Arikunto, Suharsimi. 1995. Managemen Penelitian. Jakarta: Rineka Cipta.

Hamka. 1958. Ayahku, Riwayat Hidup Dr. H. Abdul Karim Amrullah dan Perjuangan. Jakarta: Pustaka Widjaja.

Indra, Hasbi. 2012. Pendidikan Islam Tantangan \& Peluang di Era Globalisasi, $\quad$ Yogyakarta: Deepublish.

Nizar, Samsul. 2008 . Memperbincangkan Dinamika Intelektual dan Pemikiran Hamka tentang Pendidikan Islam. Jakarta: Kencana Prenada Media Group. 